\title{
Matching physical properties of food and tools in three populations of wild capuchin monkeys
}

Tiago Falótico ( $\nabla$ tfalotico@gmail.com )

Universidade de São Paulo

Tatiane Valença

Universidade de São Paulo

Michele Verderane

Neotropical Primates Research Group

Mariana Fogaça

University of Veterinary Medicine Vienna

\section{Research Article}

Keywords:

Posted Date: December 9th, 2021

DOI: https://doi.org/10.21203/rs.3.rs-1152631/v1

License: (9) This work is licensed under a Creative Commons Attribution 4.0 International License. Read Full License 


\section{Abstract}

Robust capuchin monkeys (Sapajus) are known for accessing mechanically challenging food. Although presenting morphological adaptations to do so, several populations go beyond the body limitations, using tools, mainly stone tools, to expand their food range. Those populations are diverse, some using stones more widely than others. We know stone tool size correlates with the target's resistance within some populations, but we have no detailed comparisons between populations so far. This study described and compared general environmental data, food's physical properties, and stone tools features on three populations of bearded capuchin monkeys (Sapajus libidinosus), including a new site. The differences we observed regarding stone tool use between the new site (CVNP) and the previously studied ones could be partially explained by ecological factors, such as the raw material and resource availability. However, other differences appear to be more related to behavioral traditions, such as the processing of Hymenaea at CVNP, where the monkeys use bigger stones than other populations to process the same kind of food, which present similar physical properties between sites. Possible cultural differences need to be compared within a larger number of areas to better understand capuchin monkey behavioral variability.

\section{Introduction}

Although only recently methods had been developed to measure the food's physical properties in the field ${ }^{1}$, robust capuchin monkeys (genus Sapajus) are widely and long known for accessing mechanically challenging food ${ }^{2-5}$. The genus Sapajus exhibits adaptation in the skull and postcranial skeleton that should produce increased masticatory or postcranial forces when feeding ${ }^{6,7}$. However, the several degrees of morphological variance between species is not straightforward correlated with species diet difference. For example, Sapajus apella has a more robust skull and skeleton than S. libidinosus, but the latter has a diet with a high maximum and average toughness value ${ }^{4,5}$. This counterintuitive fact may represent behavioral adaptation in opposition to morphological adaptation since S. libidinosus' use of stone tools to exploit the most challenging foods in their diet ${ }^{8-14}$. The same may happen with yellowbreasted capuchins (S. xanthosternos), which also have a more gracile skull morphology than S. apella ${ }^{7}$ and can access hard food resources using tools ${ }^{15}$.

Sapajus is one of the few extant primate genera (together with Pan, Homo, and Macaca) to customarily use stone tools to access encapsulated food ${ }^{16,17}$. However, the use of stone tools is not the same in all populations, with variations in the material and dimensions of tools used and the food resources explored. It is believed that the stone tools are chosen chiefly depending on the physical property of the target resource, and that was shown for populations of S. libidinosus, where heavier tools are used for harder food, as the stone tools used to process large palm nuts ${ }^{18-20}$. Additionally, chemical properties can also be a factor to influence the choice of a tool, as in the case of fresh cashew nut cracking at Serra da Capivara, where monkeys choose larger tools to, apparently, protect themselves from the caustic liquid from the softer fresh cashew nuts ${ }^{21}$, different from other population where the same resource is explored 
without stone tools, using a rubbing technique ${ }^{22}$. Therefore information on ecology, physical environment, and behavior, including dietary ecology and food material properties, are needed to understand the evolutionary driving forces behind anatomical and cultural changes related to food processing.

The S. libidinosus population from Serra da Capivara National Park (SCaNP) is known to present, to date, the most diverse use of stone tools. Besides using stone tools to crack open encapsulated plant resources, as in other savanna populations, they also use stone tools to aid digging for food, and for other percussive behavior, such as stone on stone to obtain powder to ingest and anoint ${ }^{20,23}$. More recently, the population of S. libidinosus of Serra das Confusões National Park (SCoNP), $100 \mathrm{~km}$ from SCaNP, was described to use stone tools to process encased food, exploring different resources, or on different frequencies, from other populations ${ }^{8}$. Another well-studied population of $S$. libidinosus is from Fazenda Boa Vista (FBV), where the monkeys appear to be specialized in cracking open hard resistant palm nuts ${ }^{12,24}$, although they also occasionally process less resistant food ${ }^{25}$. Other populations of $S$. libidinosus have been described, directly or indirectly, to use stone tools to process encapsulated, hard-tobreak food resources ${ }^{9,10}$. In no population, except for SCaNP, have capuchins been observed, so far, to habitually use stone tools for anything other than cracking encased food.

The relation between the food resource characteristics and stone tools has been studied to some extent. Although the studies do not measure the resistance of the food, they argue that stone tools are most frequently used to process high resistant fruits, such as palm nuts ${ }^{9,19,26-28}$, and there is a correlation between hammerstone weight and the apparent higher resistance of the resources ${ }^{8,19,20}$. However, there is almost no information about actual values for resistance of the resources and no comparison between capuchin populations concerning the physical properties of the accessed food regarding the features of the stone tools used in each area.

Accessing the physical properties of the food can shed light on the tool choice by capuchins to process those foods and better understand the relation between resistance of food resources and tool features. The effectiveness of the forces produced when the tool contacts the target depends on the characteristics of the food surface. These characteristics are external (e.g., size and shape) and internal mechanical properties (e.g., elastic modulus and toughness). Once the food is hit, the resistance to fragmentation is defined by the internal mechanical properties. The size, shape, and physical properties of the tool interact with the same properties of the food, and we can infer that the food breakdown is optimized to the animals' needs, saving energy. To measure the internal mechanical properties, tests record the force applied to the object and the deformation that it produces. The deformation can be registered as a forcedisplacement graphic. Hardness is the resistance to the initial loading force; in other words, the bigger the hardness value, the higher the force necessary to initiate a fracture. Elastic modulus corresponds to the material's rigidity and can also be used to estimate food resistance to the beginning of a fracture; thus, less elastic material (lower values of the elastic modulus) would be more rigid ${ }^{29}$. 
In this study, we will describe and compare lithic raw material availability, food resources physical properties, and features of the stone tools used (hammer and anvil) of three bearded capuchin monkeys (S. libidinosus) populations (Fig. 1) that use stone tools to process food resources, to test the following hypotheses:

1. Capuchin monkeys in each population select stones of adequate size to process the resources present in their living area

Prediction 1a - Hammerstone dimension will be correlated to resource hardness and elasticity, heavier stones to harder and less elastic resources

Prediction $1 \mathrm{~b}$ - Anvils dimension will be positively correlated to resource length

2. The same resources explored by capuchins in different populations have similar physical properties

Prediction 2 - The hardness and elasticity of the same resources in different areas will have similar values

\section{Results}

Stone tools dimensions of the three study sites are presented in Table 1. Stone tools at CVNP were the heaviest and largest across sites. The stone tools were composed mainly of quartzite (46.8\%), followed by sandstone $(25.2 \%)$ and limonite $(13.8 \%)$. However, each site had different patterns of stone tool material (Table 2).

The lithic raw material characteristics available for each area are presented in Table 3.

Table 1. Pounding stone tools general dimension for each site, presenting average, standard deviation, and range values. Sources: $C V N P$ - Chapada dos Veadeiros National Park (this work), SCaNP - Serra da Capivara National Park 20,35, $S C o N P$ - Serra das Confusões National Park ${ }^{8}$. 


\begin{tabular}{|c|c|c|c|c|c|}
\hline & $\mathbf{N}$ & Weight (g) & Length (mm) & Width (mm) & Thickness (mm) \\
\hline \multicolumn{6}{|l|}{ CVNP } \\
\hline \multirow[t]{3}{*}{ Anvil } & 119 & - & $499 \pm$ SD 270.9 & $315.3 \pm$ SD & $162.5 \pm \mathrm{SD}$ \\
\hline & & & $57-1750$ & 176.5 & 138.6 \\
\hline & & & & $90-870$ & $20-900$ \\
\hline \multirow[t]{2}{*}{ Hammer } & 140 & $1672.2 \pm \mathrm{SD}$ & $152.8 \pm$ SD 41.6 & $102.8 \pm$ SD 26.9 & $74.5 \pm$ SD 63.7 \\
\hline & & $\begin{array}{l}1050.6 \\
266-5700\end{array}$ & $71-285$ & $52-195$ & $20-790$ \\
\hline \multicolumn{6}{|l|}{ SCaNP } \\
\hline \multirow{2}{*}{ Hammer } & 542 & $202.5 \pm$ SD 209.1 & $70.1 \pm$ SD 23.6 & $52.2 \pm$ SD23.1 & $37 \pm$ SD 12 \\
\hline & & $18-1900$ & $31.5-210$ & $24-427$ & $14-84$ \\
\hline \multicolumn{6}{|l|}{ SCoNP } \\
\hline \multirow[t]{3}{*}{ Anvil } & 57 & - & $449.5 \pm \mathrm{SD}$ & $309.4 \pm \mathrm{SD}$ & - \\
\hline & & & 256.9 & 183.7 & \\
\hline & & & $88-1410$ & 48-970 & \\
\hline \multirow[t]{2}{*}{ Hammer } & 69 & $316 \pm$ SD 254.4 & $96.6 \pm$ SD 30.7 & $56.8 \pm$ SD 15.7 & $33.6 \pm$ SD 11.4 \\
\hline & & 31.4-1409 & $44.7-210$ & $29.8-95.3$ & $12.5-66.8$ \\
\hline
\end{tabular}

Table 2. Lithic material of stone tools in each site.

\begin{tabular}{|c|c|c|c|c|}
\hline Site & $\mathbf{N}$ & Conglomerate & Limonite & Quartz Sandstone \\
\hline CVNP & 180 & & $19.4 \%$ & $58.9 \% 21.7 \%$ \\
\hline SCaNP & 239 & $0.8 \%$ & $1.3 \%$ & $89.1 \% \quad 8.8 \%$ \\
\hline SCoNP & & 0 & $59.4 \%$ & $40.6 \%$ \\
\hline
\end{tabular}

Table 3. Lithic raw material characteristics in each area, from plot samples. Stones with more than $3 \mathrm{~cm}$ were classified.

\begin{tabular}{cllllll} 
& $\mathbf{N}$ & $\begin{array}{l}\text { Average } \\
\text { Weight }\end{array}$ & $\begin{array}{l}\text { StdDev } \\
\text { Weight }\end{array}$ & $\begin{array}{l}\text { Average } \\
\text { Length (cm) }\end{array}$ & $\begin{array}{l}\text { Density } \\
\text { (stone/ha) }\end{array}$ & $\begin{array}{l}\text { \% } \\
\text { material }\end{array}$ \\
\hline CVNP & $\mathbf{2 1 6}$ & $\mathbf{2 1 6 . 3}$ & $\mathbf{5 7 4 . 1}$ & $\mathbf{6 . 5}$ & $\mathbf{4 8 0}$ & \\
\hline Quartz & 97 & 297.6 & 770.1 & 7.0 & 215.5 & $44.9 \%$ \\
\hline Sandstone & 17 & 86.2 & 158.5 & 5.1 & 37.8 & $7.9 \%$ \\
\hline Limonite & 100 & 154.9 & 346.7 & 6.2 & 222.2 & $46.3 \%$ \\
\hline Conglomerate & 2 & 447.5 & 218.5 & 12.1 & 4.4 & $0.9 \%$ \\
\hline SCaNP & $\mathbf{1 8 8}$ & $\mathbf{1 1 3 . 5}$ & $\mathbf{1 8 5 . 1}$ & $\mathbf{5 . 5}$ & $\mathbf{4 1 7 . 8 4}$ & \\
\hline Quartz & 145 & 104.1 & 180.1 & 5.0 & 322.2 & $77.1 \%$ \\
\hline Sandstone & 43 & 145.0 & 199.8 & 7.2 & 95.5 & $22.9 \%$ \\
\hline SCoNP & $\mathbf{1 7 6}$ & $\mathbf{1 4 9 . 8}$ & $\mathbf{2 8 1 . 1}$ & $\mathbf{6 . 6}$ & $\mathbf{3 9 1 . 1}$ & \\
\hline Sandstone & 70 & 164.3 & 277.0 & 6.8 & 155.5 & $39.8 \%$ \\
\hline Limonite & 105 & 140.8 & 285.9 & 6.4 & 233.3 & $59.7 \%$ \\
\hline Resin & 1 & 85.4 & - & 10.3 & 2.2 & $0.6 \%$
\end{tabular}


The primary food resource found at the anvils during the mapping at CVNP was Attalea palm nut (91\%); Hymenaea remains were found in only 3\% of the mapped anvils. At SCoNP, the main resources found in the anvils were Buchenavia fruits (38\%), Manihot (31\%), Hymenaea (19\%), and Attalea maripa nuts (11\%); the remaining $1 \%$ was not identified ${ }^{8}$.

The physical properties test results (Indentation Hardness and Reduced Elastic Modulus) on the resources sampled in each area (Fig. 2), plus the average of stone tools recorded to process each resource in each area, are presented in Table 4.

Table 4. Physical properties (indentation hardness and elastic modulus) of the food resources processed with stone tools in each area and the average stone tool weight the capuchin monkeys use to process each resource type. Some values are not available (n.a.) because the monkeys were not observed to process the resource with stone tools in that population. 
Resource N

Avg of Var of Indentation Indentation

Hardness

(MPa)

Hardness

(MPa)

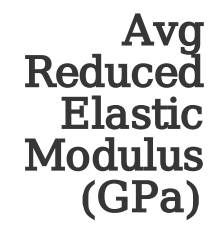

Var of Reduced

Elastic

Modulus

(GPa)

$\begin{array}{rr}\text { Avg } & \text { Avg } \\ \text { Length } & \text { stone } \\ \text { tool } \\ \text { (resource, } \\ \text { mm) } & \text { weight } \\ & (\mathrm{g})\end{array}$

\begin{tabular}{|c|c|c|c|c|c|c|c|}
\hline Anacardium & 33 & 3.40 & 30.62 & 0.0642 & 0.0085 & 37.79 & $\begin{array}{r}195.8 \\
(n=34)\end{array}$ \\
\hline dry nut & 11 & 8.56 & 52.62 & 0.1559 & 0.0128 & 32.55 & \\
\hline SCaNP & 5 & 13.72 & 59.03 & 0.2472 & 0.0094 & 32.28 & $\begin{array}{r}186.9 \\
(n=12)\end{array}$ \\
\hline SCoNP & 6 & 4.27 & 9.21 & 0.0799 & 0.0028 & 32.78 & n.a. \\
\hline fresh nut & 22 & 0.81 & 0.62 & 0.0184 & 0.0002 & 40.41 & \\
\hline SCaNP & 9 & 1.28 & 1.07 & 0.0206 & 0.0003 & 49.78 & $\begin{array}{r}204.8 \\
(n=22)\end{array}$ \\
\hline SCoNP & 13 & 0.49 & 0.08 & 0.0168 & 0.0002 & 33.92 & n.a. \\
\hline \multicolumn{8}{|l|}{ Attalea } \\
\hline CVNP & 21 & 104.68 & 8292.14 & 3.7363 & 10.2854 & 63.33 & $\begin{array}{r}1822 \\
(\mathrm{n}=71)\end{array}$ \\
\hline Hymenaea\# & 21 & 36.25 & 279.70 & 0.8845 & 0.2090 & 122.64 & $\begin{array}{r}537.9 \\
(n=44)\end{array}$ \\
\hline CVNP & 5 & 24.08 & 20.82 & 0.5550 & 0.0088 & 122.64 & $\begin{array}{r}1011.2 \\
(\mathrm{n}=4)\end{array}$ \\
\hline SCaNP* & 7 & 35.12 & 133.16 & 1.1014 & 0.2636 & - & $\begin{array}{r}249.2 \\
(\mathrm{n}=14)\end{array}$ \\
\hline SCoNP & 9 & 42.54 & 436.88 & 0.8622 & 0.1994 & - & $\begin{array}{r}353.3 \\
(n=26)\end{array}$ \\
\hline Manihot & 72 & 118.24 & 5372.13 & 2.1150 & 5.6642 & 16.42 & $\begin{array}{r}195.3 \\
(n=50)\end{array}$ \\
\hline SCaNP & 43 & 83.58 & 2288.33 & 2.1973 & 8.7312 & 15.73 & $\begin{array}{r}169.3 \\
(n=30)\end{array}$ \\
\hline SCoNP & 29 & 169.64 & 5607.83 & 1.9931 & 1.2401 & 17.30 & $\begin{array}{r}221.4 \\
(n=20)\end{array}$ \\
\hline
\end{tabular}

Buchenavia

SCoNP 10

$51.52 \quad 1026.75$

0.7732

0.3160

16.09

342 $(n=18)$

* Data on stone tool weight for Hymenaea in SCaNP from ${ }^{35}$

\# The Hymenaea species at SCoNP is $H$. martiana, and in SCaNP is $H$. courbaril. The species sampled at CVNP is unknown, as there are two similar species in the area, $H$. courbaril and $H$. stignocarpa ${ }^{30}$. We compared them at the genus level in this work. 


\section{Comparison within populations}

The resource physical properties and stone tools used to process those items in each population are summarized in Fig. 3 and 4.

In CVNP, the two resources (Hymenaea pods and Attalea palm nuts) analyzed were different in hardness (Kruskal-Wallis, $\mathbb{\bigotimes}^{2}=3.63, d f=1, p=0.057$ ) and elasticity (Kruskal-Wallis, $\mathbb{x}^{2}=5.33, d f=1, p=0.021$ ). Still, the hammer stone weight was not significantly different $\left(\mathbb{Z}^{2}=2.14, d f=1, p=0.143\right)$. We take this result cautiously because we only had four tool sites used to process Hymenaea in our sample.

In SCaNP, the resources (Hymenaea pods, Manihot seeds, and Anacardium cashew nuts) had significant differences in hardness, elasticity, and weight of the stone tools associated (Kruskal-Wallis, $\mathbb{\otimes}^{2}=37.348$, $\left.d f=3, p<0.001 ; \mathbb{Z}^{2}=33.005, d f=3, p<0.001 ; \mathbb{Z}^{2}=8.533, d f=3, p=0.036\right)$. However, the weight of the stones was only significantly different in one pairwise comparison, revealing that the only difference was between hammer stones to process Hymenaea pods and Manihot seeds (Mann-Whitney, Z=-2.948, $p=0.003$ ), the latter processed with lighter stone tools.

Finally, in SCoNP, the resources (Buchenavia seeds, Hymenaea pods, Manihot seeds, and Anacardium cashew nuts) had significant differences in hardness and elasticity (Kruskal-Wallis, $\mathbb{\bigotimes}^{2}=55.493, \mathrm{df}=4$, $\left.p<0.001 ; \otimes^{2}=50.203, d f=4, p<0.001\right)$. Pairwise comparison showed that the only resources that did not significantly differ in the tested properties were Buchenavia seeds and Hymenaea pods (hardness, MannWhitney, $Z=-0.816, p=0.447$; elasticity, Mann-Whitney, $Z=-0.568, p=0.604)$. The hammerstones associated with the resources did not significantly differ (Kruskal-Wallis, $\mathbb{\Xi}^{2}=3.364, d f=2, p=0.186$ ).

Regarding anvils, we found no differences in the length related to the food resources processed with stone tools (Kruskal-Wallis, $\mathbb{\bigotimes}^{2}=1.516, \mathrm{df}=3, \mathrm{p}=0.679$ ).

\section{Comparison between populations}

To analyze the differences between populations, we compared the resources present in more than one site and the stone tools used to process those items.

Attalea palm nuts, Buchenavia seeds, and the associated stone tools were not quantitatively evaluated because they are present in only one of the study sites.

Fresh cashew nuts sampled in SCaNP and SCoNP were similar in elasticity (Mann-Whitney, Z=55, $p=0.845$ ) but had significantly different values for hardness (Mann-Whitney, $Z=25, p=0.025$ ). As for dry cashew, we found significant differences in both physical properties (Mann-Whitney, $Z=23, p=0.017$; 
Mann-Whitney, $Z=23, p=0.018$ ), with SCaNP nuts being harder and less elastic. We could not compare stone tools for cashews because SCoNP monkeys had not been observed to explore this resource, with or without tools ${ }^{8,31}$.

Manihot seeds from SCaNP and SCoNP differed significantly regarding physical properties (MannWhitney, $Z=1013, p<0.001$; Mann-Whitney, $Z=800, p=0.043)$, SCoNP seeds were harder and less elastic. The stones used to process those resources were heavier at SCoNP, the difference was not significant, but there was a trend (Mann-Whitney, $Z=387, p=0.085$ ).

The Hymeanae pods were the only resource analyzed in all three sites. We found no differences in physical properties between the jatobá fruits (Hardness, Kruskal-Wallis, $\mathbb{\nabla}^{2}=0.978, d f=2, p=0.613$; Elasticity, $\left.\mathbb{Q}^{2}=1.360, d f=2, p=0.507\right)$. Even though some of those resources are possibly from different species, the properties are similar. On the other hand, the hammerstone tools were significantly different in weight (Kruskal-Wallis, $\mathbb{Z}^{2}=15.529, \mathrm{df}=2, \mathrm{p}<0.001$ ). The difference was between the stones from CVNP and the other sites (Mann Whitney, $Z=-22.569, p<0.001 ; Z=-20.444, p<0.001)$. The weight of hammerstone tools to process Hymenaea pods from SCaNP and SCoNP were not different (Mann Whitney, Z=-2.214, $\mathrm{p}<0.649$ ).

\section{Discussion}

This work compared wild capuchin monkeys from three areas, describing the stone tool use in a new $S$. libidinosus population and comparing the resources processed within and between sites. We also describe the physical properties of the resources and the stone tools used to process those foods and compare the data between the three sites and the literature.

The new site described, CVNP, has a typical tropical savannah (Cerrado) capuchin stone tool use pattern. The capuchins mostly use stone tools to crack open a high resistant palm nut (Attalea), similar to those processed in other savannah environments $9,15,18$. However, the weight of the tools and the physical properties of the food accessed in this site were bigger than the other two populations analyzed (and also from the literature). Stone tools in CVNP had an average weight of $1672 \mathrm{~g}$. The heaviest stone tool registered in our mapping was $5700 \mathrm{~g}$ (Table 1 ). In latter camera-trap surveillance (data not presented here, see supplementary video files for examples), we recorded monkeys effectively using a $4650 \mathrm{~g}$ stone tool (Fig. 5), an astonishing weight to be lifted by monkeys with a body mass average of $3500 \mathrm{~g}$ for adult males and $2100 \mathrm{~g}$ for adult females ${ }^{32}$. At the other two sites, the resources explored had lower hardness values, and the stone tools used to pound food resources were lighter, as expected based on other capuchin populations choosing stones according to the resistance of the resource processed ${ }^{8,12,19}$. 
CVNP has a high density ( 215 stones/ha) of quartzite pebbles (the best raw material for stone tools) (Table 3), making it much more likely for the monkeys to encounter and use it than other stones available. Furthermore, the quartzite pebbles in this site are on average larger than the stones available at the other sites, maybe allowing CVNP's monkeys to more often use heavy stones, close to the limit of their lift capacities. Thus, this environmental difference could partially explain the use of larger tools for the CVNP population.

The high availability of quartzite in SCaNP (the higher among the compared sites, 322 stones/ha) could explain the more diversity of stone tool use observed in that area than any other site $8,20,23,33$. However, we probably do not have a complete knowledge of the repertoire of stone tool use at CVNP to compare those sites thoroughly and better understand the mechanism underlying tradition on the use of tools.

One of the resources explored with stone tools in CVNP is jatobá pods (Hymenaea sp.), although much less frequently than the palm nuts, at least in the study areas we mapped. The stone tools were, as expected, lighter than the ones used to process the harder palm nuts, although not statistically significant. This result may be related to the small sample of Hymenaea tools.

Jatobá pods were the only resource present in all three populations compared here. Our results showed that the physical properties of the pods were not significantly different across sites, meaning the challenge to open the pods would be similar in all three areas. However, the weight of the stone tools used in each population was different. CVNP monkeys used much larger stones to process the pods than the monkeys from the other two populations. One explanation could be the availability of the potential material to be used as tool. As mentioned before, CVNP has the larger/heavier raw stone material availability (Table 3). An alternative explanation would be related to the other resources explored. At the CVNP area, the monkeys explore, at the same nut-cracking sites, and with higher frequency, a much harder food (Attalea nuts), which could bias the tools selection to larger stones because of those more resistant palm nuts.

To better understand the tool use repertoire at CVNP, we still need to directly observe the monkeys or perform experimental tests to check the existence (or not) of tool use observed in other populations (e.g., probe tools, digging stones). The use of camera-traps recording nut-cracking sites (analysis ongoing) will also allow the observation of the stone tool use, its efficiency, and variation.

The first prediction of hypothesis 1 was not supported in any of the analyzed populations. Heavier stone tools were not correlated to process harder food. In the case of CVNP, we had a small sample for stone tools used for Hymenaea, and both resources analyzed were found close to each other, so the stone selection at that area could have been biased to the process of the harder Attalea nuts. In the case of SCoNP, stone tools' weights did not differ between Hymenaea and Manihot seeds. Two things could explain this difference. First, in SCoNP, the lithic raw material is scarcer than in CVNP and SCaNP, restricting the selection of tools. Second, although small (Avg length, 16.42mm), Manihot seed showed 
surprisingly higher hardness values, perhaps requiring a similar stone tool to the ones used to open the larger Hymenaea. Considering only the hardness value, we would expect that the monkeys would use heavier stones to access Manihot. However, in SCaNP, the stones used to crack Manihot were lighter than Hymenaea. One possible explanation is that although Hymenaea is much larger, scaling hardness with size does not consider the combination of structural and material compensation (the result of the heterogeneity and anisotropy of the food resource). Taking into account the structure of the food resources, could be helpful in future studies to clarify the stone dimension and food physical properties.

The second prediction for $\mathrm{H} 1$ was not supported also. The anvil length did not vary by resource size. Our explanation is that an adequate anvil can be successfully used to process most resources. So, not being a limiting factor that needs to be different for most resources, e.g., the same anvil used to process an Attalea nut could be potentially used for Hymenaea pods, particularly when both species occur near each other. Even when a small target, such as manihot, is being processed, the choice of an anvil could be driven by the larger resource in the area (rule of thumb to choose larger anvils), as this larger anvil can be used for any resource and there are no energetic costs, as it is not transported. A factor that should be analyzed in the future is the inclination of the anvil or the presence of pits, as some resources are rounder and more prone to roll from a tilted anvil, meaning this factor could be more critical for anvil selection depending on the type of resource to be placed on the anvil.

Our results show a more complex association between food physical properties and tool selection than previous studies $12,19,20$. The data presented here also suggest that variables can interact, such as food size and hardness, and reflect on tool selection. In this way, our results have reshaped our understanding of tool selection considering physical properties. Our results suggest a hierarchical approach to the tool choice considering food hardness, size, and stones available to choose in the environment. Future work testing the relationships between physical properties and tool selection in other taxa will improve the generalizability of these results.

Hypothesis 2 was supported for Hymenaea pods and fresh cashews but not for dry cashews and manihot seeds.

Hymenaea pods and fresh cashews did not differ in the physical properties between sites, even though the Hymenaea in each place are from different species. That allows an interesting comparison between the use of stone tools to open this resource, as it is processed with stones of different weight even being similar regarding physical properties. The same is true, in part, for the green cashew nuts, although in this case, the chemical characteristics could also be a factor of influence ${ }^{21}$.

We found differences in hardness and elasticity between the study sites for manihot and dry cashews. The difference between physical properties for the same species in different sites can be related to the time lying on the ground. Cashew nuts can lay on the floor for a long time (days or even months) before being picked by the monkeys (T.F. personal observation), and our sampling reflects that, as we collected a 
mix of dry nuts from the ground and also directly from the tree. Therefore, we would expect the loss of water content to turn the tissues less elastic and harder (Gerolamo et al., submitted). The influence of the effects of the environment on the physical properties could also explain the difference found for manihot seed; even if similar to the naked eye, we may have sampled seeds in different stages of desiccation.

Robust capuchin monkeys are known to explore mechanically tough food, however, populations that do not use stone tools must rely only on their bodies to do so. That presents a series of limitations. Nevertheless, capuchins have features that facilitate the production of large muscle and bite forces without compromising gape and so can exploit mechanically challenging foods at relatively large jaw gapes. But Attalea and Hymenaea are larger/bigger than the jaw gape of the monkeys and could only be opened by hand or using tools, and that appears to be the case. The monkeys at the analyzed populations (and other previously studied) have shown that the use of stone tools provides access to hard-encased food that would not be accessible otherwise. Even for smaller food targets, e.g., Manihot seeds and cashew nuts, the efficiency of using tools to access those targets could be higher, especially if the population already has the tool use behavior in their repertoire because of the more challenging targets that obligatory need stone tools to be accessed, as appears to be the case of the populations in this study.

The differences we observed regarding stone tool use between the new site (CVNP) and the previously studied ones could be partially explained by ecological factors, such as the availability of lithic material and food resources. When processing similar food, such as Hymenaea, each population appears to be limited by the stones available, reflecting on the stone choice. Even the presence of other food resources can bias the tool choice, as the Attalea nuts presence appears to do at CVNP. However, some differences are more subtle. Even though cashew nuts were available and softer than cashew nuts present in the SCaNP population, SCoNP monkeys do not eat cashew nuts, with or without stone tools ${ }^{31}$. Since the absence of consumption of this food resource in SCoNP is neither because of availability or impossibility of access, one could argue that this difference is a cultural behavior. Cashew nuts possess mechanical and chemical defense mechanisms ${ }^{21}$ that need to be dealt with, and that behavior could be socially learned.

To better understand the variation on resource exploitation, including tool use, by capuchin monkeys, we still need more information from new sites to have other examples to correlate with the possible ecological and cultural factors.

\section{Methods}

\section{Study sites}


Serra da Capivara National Park (SCaNP, -8.833239, -42.552377) and Serra das Confusões National Park (SCoNP, -9.213317, -43.498371) are located in the south of Piauí state (Fig. 1), Brazil. Both parks have Caatinga (thornbush savannah) as the predominant biome and semiarid as the prevailing climate. Still, the west area of SCoNP is an ecotone with the biome Cerrado (tropical savannah). The vegetation is xerophytic, especially at higher elevations, but there are patches of deciduous forest in the humid valleys surrounded by high cliffs.

SCaNP has an area of 130,000 ha, with an average temperature of $28^{\circ} \mathrm{C}$ (range $10-47^{\circ} \mathrm{C}$ ) and a mean annual rainfall of $689 \mathrm{~mm}$. This region is composed of Serra Grande formation, which has sandstones and conglomerates, and Canindé Group, which has laminated shale, sandstones, tempestites, mudstones, cobbles, and siltstones (for more details, see ${ }^{34,35}$ ).

SCoNP has 823,435 ha of area, in which the average temperature is $28^{\circ} \mathrm{C}$ (range $12-45^{\circ} \mathrm{C}$ ), and the mean annual rainfall is $650 \mathrm{~mm}$. There are also more humid areas (Cerrado) in the east and north of SCoNP and some intermittent rivers in the valleys. This park presents three geological formations: Cabeça, which has hard sandstones; Pimenteiras, having red shale, sandstones, and siltstones; and Serra Grande, which has conglomeratic sandstone and quartz pebbles (for more details, see ${ }^{8}$ ).

Chapada dos Veadeiros National Park (CVNP, -14.093696, -47.373306) was created in 1961 in the northeast of Goiás State (Fig. 1), in a central region of Brazil. This site has an area of 240,611 ha characterized by Cerrado biome and a tropical savanna climate. It has annual rainfall ranging from 1,500 to $1,750 \mathrm{~mm}$, most of it occurring during the wet season (November to March), and average temperatures ranging from $20^{\circ}$ to $27^{\circ} \mathrm{C}{ }^{30}$. The region encompasses waterfalls and three rivers descending from high plateaus of altitudes up to $1,676 \mathrm{~m}$, erosional scraps, and intra-plateau depressions ${ }^{36}$. This high altitude and water availability enable a mosaic of vegetation, including more open areas as grassland and open scrubland, wet areas as gallery forests, until more dense areas with taller trees, as forest and wooded savanna ${ }^{30}$. In terms of geomorphology, CVNP is in the Brazilian Central Plateau and is formed by Araí Group, that includes the basement granite gneiss and contains quartzites, conglomerates, calcareouspelitic rocks, sandstones, basalts, and siltstones; and also by Paranoá Group, which is above the Araí group and contains metasediments, including quartzites, metasiltstones, limestones and dolostones ${ }^{36}$.

\section{Tool sites and environmental sampling}


The stone tool use site mapping at CVNP was done following the same method of previous work ${ }^{8}$. For nine days (June $6-16,2019)$, three researchers and a local field assistant walked $28.7 \mathrm{~km}$ of tracks on two locations at the south of the park (Mariri: -14.10691, -47.44084; Terra Booma: -14.07716, -47.48388; Fig. 6), actively looking for stone tool use processing sites. Both locations have at least one resident $S$. libidinosus group.

A "processing site" was characterized by the following items: (1) "anvil", a flat surface used as a substrate for the processed encased food, (2) "hammer" on top or beside the anvil (within $1 \mathrm{~m}$ ), and (3) remains of the processed encased food atop or adjacent (within $30 \mathrm{~cm}$ ) to the anvil ${ }^{37}$.

When a processing site was identified, we recorded the following variables: GPS coordinates, anvil material and size (maximum length and width), stone tool material, weight and size (length, width, and thicknesses), and processed encased food. We used digital scales (to nearest $0.1 \mathrm{~g}$ ), calipers (to nearest $0.1 \mathrm{~mm}$ ), and measuring tapes (to nearest $\mathrm{mm}$ ). We visually identified processed encased foods in each site and collected samples from nearby trees for botanical identification. We collected the remaining of processed resources at anvils for the physical properties test (see below).

Samplings of processing sites and description of S. libidinosus tool use at ScaNP and SCoNP were done in previous studies ${ }^{8,20}$. Still, we revisited both locations in October/2019 to collect food samples for physical properties testing and plot samples (see below). We collected Manihot, Annacardium, and Hymenaea samples in the same areas of the previous works. At SCaNP, we collected additional behavioral data on tool use throughout two study periods with the Pedra Furada (PF) group (2018 and 2019). TF followed this group for a total of 242 hours, recording all occurrences of tool use and measuring the tools used with the same protocol as above after the monkeys left. The PF group was also studied and described in previous studies in this area $20,21,23,38$. The data on the stone tools is available in Supplementary Table 1.

To characterize the availability of raw lithic material, we did plot samples at the three sites, in the living area of groups Pedra Furada (SCaNP), Gruta do Boi (SCoNP), and Mariri (CVNP). Forty-five plots of $10 \times 10 \mathrm{~m}$ were done along $4.5 \mathrm{~km}$ transect lines, in $100 \mathrm{~m}$ intervals, covering the living area of at least one group of capuchin monkeys as part of a broader survey for ecological description. We identified stone tool use sites with the same methodology as above in each plot. To evaluate stone material and the amount available in the areas, we did a $50 \times 50 \mathrm{~cm}$ subplot at the $S W$ corner of each plot, where all stones with more than $3 \mathrm{~cm}$ were counted and classified by rock type, measured, and weighted.

\section{Food resources physical properties test}

Mechanics were measured with a Lucas Scientific FLS-2 portable mechanical tester ${ }^{1,39}$. Although hardness is not a property per se, it is a derived concept traditionally used to measure the resistance to 
deforming under indentation. The technology of the equipment used can measure indentation of millimeter dimensions bringing more accurate results for such tests. The test used is called sharp indent (for more details, see ${ }^{40}$ ) and, in addition to the hardness values, gives us the elastic modulus, defined as the ratio of stress to strain in the elastic region ${ }^{41}$. Following an initial force loading, the displacement is held constant while recording the force decay for further 90 s or until the load stabilizes, forming a curve. Fitting a curve to the relaxation behavior allows the calculation of both an instantaneous (Ei) and infinite $(E \infty)$ elastic modulus. "Ei" represents the elastic modulus of a material if it could be loaded instantly, while "E $\infty$ " estimates the elastic behavior under an infinitely slow loading regime. In this study, we use "Ei" measurements, which are likely more relevant when investigating how food behaves under chewing loads 42.

\section{Analyses}

The resources' hardness and elastic modulus values were compared using Kruskal-Wallis (KW) tests. Pairwise comparisons of values within and between sites were performed using post-hoc Mann-Whitney $\mathrm{U}$ tests with a Bonferroni correction for multiple comparisons. Analyses were performed in R 4.043 .

\section{References}

1. Darvell, B. W., Lee, P. K. D., Yuen, T. D. B. \& Lucas, P. W. A portable fracture toughness tester for biological materials. Meas Sci Technol 7, 954 (1996).

2. Terborgh, J. Five New World Primates: A Study in Comparative Ecology. (Princeton University Press, 1983).

3. Laird, M. F. et al. Ingestive behaviors in bearded capuchins (Sapajus libidinosus). Sci Rep 10, 20850 (2020).

4. Chalk, J. et al. Age-related variation in the mechanical properties of foods processed by Sapajus libidinosus. Am J Phys Anthropol 159, 199-209 (2015).

5. Fogaça, M. D., Yamashita, N., Izar, P., Vinyard, C. J. \& Wright, B. Dietary toughness and implications for fallback food theory. (in preparation).

6. Wright, K. A. et al. The effects of ecology and evolutionary history on robust capuchin morphological diversity. Mol Phylogenet Evol 82, 455-466 (2015).

7. Cáceres, N. et al. Ecogeographical variation in skull shape of capuchin monkeys. J Biogeogr 41, 501512 (2014). 
8. Falótico, T., Coutinho, P. H. M., Bueno, C. Q., Rufo, H. P. \& Ottoni, E. B. Stone tool use by wild capuchin monkeys (Sapajus libidinosus) at Serra das Confusões National Park, Brazil. Primates 59, 385-394 (2018).

9. Mendes, F. D. C. et al. Diversity of nutcracking tool sites used by Sapajus libidinosus in Brazilian Cerrado. Am J Primatol 77, 535-546 (2015).

10. Moraes, B. L. C. D., Souto, A. D. S. \& Schiel, N. Adaptability in stone tool use by wild capuchin monkeys (Sapajus libidinosus). Am J Primatol 76, 967-977 (2014).

11. Ottoni, E. B. \& Izar, P. Capuchin monkey tool use: overview and implications. Evol Anthropol 17, 171178 (2008).

12. Spagnoletti, N., Visalberghi, E., Ottoni, E., Izar, P. \& Fragaszy, D. Stone tool use by adult wild bearded capuchin monkeys (Cebus libidinosus). Frequency, efficiency and tool selectivity. J Hum Evol 61, 97-107 (2011).

13. Lambert, J. E. Seasonality, fallback strategies, and natural selection. in Evolution of the Human Diet (ed. Ungar, P. S.) 324-343 (Oxford University Press, 2007).

14. Marshall, A. J., Boyko, C. M., Feilen, K. L., Boyko, R. H. \& Leighton, M. Defining fallback foods and assessing their importance in primate ecology and evolution. Am J Phys Anthropol 140, 603-614 (2009).

15. Canale, G. R., Guidorizzi, C. E., Kierulff, M. C. M. \& Gatto, C. A. F. R. First record of tool use by wild populations of the yellow-breasted capuchin monkey (Cebus xanthosternos) and new records for the bearded capuchin (Cebus libidinosus). Am J Primatol 71, 366-372 (2009).

16. McGrew, W. C., Falótico, T., Gumert, M. D. \& Ottoni, E. B. A Simian View of the Oldowan. in Squeezing Minds From Stones (eds. Overmann, K. A. \& Coolidge, F. L.) 13-41 (Oxford University Press, 2019). doi:10.1093/oso/9780190854614.003.0002.

17. Haslam, M. et al. Primate archaeology evolves. Nat Ecol Evol 1, 1431-1437 (2017).

18. Visalberghi, E. et al. Characteristics of hammer stones and anvils used by wild bearded capuchin monkeys (Cebus libidinosus) to crack open palm nuts. Am J Phys Anthropol 132, 426-444 (2007).

19. Ferreira, R. G., Emidio, R. A. \& Jerusalinsky, L. Three stones for three seeds: natural occurrence of selective tool use by capuchins (Cebus libidinosus) based on an analysis of the weight of stones found at nutting sites. Am J Primatol 72, 270-275 (2010).

20. Falótico, T. \& Ottoni, E. B. The manifold use of pounding stone tools by wild capuchin monkeys of Serra da Capivara National Park, Brazil. Behaviour 153, 421-442 (2016). 
21. Luncz, L. V. et al. Wild capuchin monkeys adjust stone tools according to changing nut properties. Sci $\operatorname{Rep}$ 6, 33089 (2016).

22. Sirianni, G. \& Visalberghi, E. Wild bearded capuchins process cashew nuts without contacting caustic compounds. Am J Primatol 75, 387-393 (2013).

23. Falótico, T., Siqueira, J. O. \& Ottoni, E. B. Digging up food: excavation stone tool use by wild capuchin monkeys. Sci Rep 7, 6278 (2017).

24. Visalberghi, E. et al. Physical properties of palm fruits processed with tools by wild bearded capuchins (Cebus libidinosus). Am J Primatol 70, 884-891 (2008).

25. Visalberghi, E., Barca, V., Izar, P., Fragaszy, D. \& Truppa, V. Optional tool use: The case of wild bearded capuchins (Sapajus libidinosus) cracking cashew nuts by biting or by using percussors. Am J Primatol 83, e23221 (2021).

26. Coelho, C. G. et al. Social learning strategies for nut-cracking by tufted capuchin monkeys (Sapajus spp.). Anim Cogn 18, 911-919 (2015).

27. Ottoni, E. B. \& Mannu, M. Semifree-ranging tufted capuchins (Cebus apella) spontaneously use tools to crack open nuts. Int J Primato/ 22, 347-358 (2001).

28. Spagnoletti, N. et al. Stone tool use in wild bearded capuchin monkeys, Cebus libidinosus. Is it a strategy to overcome food scarcity? Anim Behav 83, 1285-1294 (2012).

29. Lucas, P. W. Dental Functional Morphology. (2004) doi:10.1017/cbo9780511735011.

30. ICMBIO. Plano de Manejo Parque Nacional Chapada dos Veadeiros - GO. (2009).

31. Coutinho, P. H. M. Investigação do uso espontâneo de ferramentas por macacos-prego selvagens (Sapajus libidinosus) do Parque Nacional Serra das Confusões - PI. Doctorate thesis, Institute of Psychology, University of São Paulo (2021) doi: 10.11606/T.47.2021.tde-28052021-141937.

32. Fragaszy, D. M. et al. Body mass in wild bearded capuchins, (Sapajus libidinosus): ontogeny and sexual dimorphism. Am J Primatol 78, 473-484 (2016).

33. Ottoni, E. B. The lasting and the passing: behavioural traditions and opportunities for social learning in wild tufted capuchin monkeys. in Comparative Cognition, Commonalities and Diversity (eds. Anderson, J. R. \& Kuroshima, H.) 153-169 (Springer Nature Singapore, 2021). doi:10.1007/978-981-16-2028-7_10.

34. Mutzenberg, D. da S., Correa, A. C. de B., Tavares, B. de A. C. \& Cisneiros, D. Serra da Capivara National Park: Ruinform Landscapes on The Parnaiba Cuesta. in Landscapes and Landforms of Brazil. World Geomorphological Landscapes (eds. Vieira, B. C., Salgado, A. A. R. \& Santos, L. J. C.) 253-263 (Springer, 2015). doi:10.1007/978-94-017-8023-0_23. 
35. Mannu, M. \& Ottoni, E. B. The enhanced tool-kit of two groups of wild bearded capuchin monkeys in the Caatinga: tool making, associative use, and secondary tools. Am J Primatol 71, 242-251 (2009).

36. Júnior, O. A. de C., Guimarães, R. F., Martins, É. de S. \& Gomes, R. A. T. Chapada dos Veadeiros: The Highest Landscapes in the Brazilian Central Plateau. in Landscapes and Landforms of Brazil. World Geomorphological Landscapes (eds. Vieira, B. C., Salgado, A. A. R. \& Santos, L. J. C.) 221-230 (Springer, 2015). doi:10.1007/978-94-017-8023-0_20.

37. Visalberghi, E., Haslam, M., Spagnoletti, N. \& Fragaszy, D. M. Use of stone hammer tools and anvils by bearded capuchin monkeys over time and space: construction of an archeological record of tool use. $J$ Archaeol Sci 40, 3222-3232 (2013).

38. Falótico, T. \& Ottoni, E. B. Stone throwing as a sexual display in wild female bearded capuchin monkeys, Sapajus libidinosus. Plos One 8, e79535 (2013).

39. Lucas, P. W. et al. Field kit to characterize physical, chemical and spatial aspects of potential primate foods. Folia Primatol 72, 11-25 (2001).

40. Lucas, P. W. et al. Indentation as a technique to assess the mechanical properties of fallback foods. Am J Phys Anthropol 140, 643-652 (2009).

41. Lucas, P. W. Dental functional morphology: how teeth work. (Cambridge University Press, 2007).

42. Casteren, A. van, Venkataraman, V., Ennos, A. R. \& Lucas, P. W. Novel developments in field mechanics. J Hum Evol 98, 5-17 (2016).

43. R Core Team. R: A language and environment for statistical computing. R Foundation for Statistical Computing. (2021). https://www.R-project.org

\section{Declarations}

\section{Acknowledgments}

We would like to thank Paulo Henrique M. Coutinho and Piquerobi Freitas Pereira de Souza for their assistance during fieldwork, Mariri Jungle Lodge, and Terra Booma for authorization to enter their lands. Karin Stefanie Ibirocahy Wutzl and Marianne K. Soisalo for the warm reception and accommodation.

The following grants supported this study: TF \#2019/00716-2, \#2018/01292-9, São Paulo Research Foundation (FAPESP); TV \#2019/10155-8, São Paulo Research Foundation (FAPESP).

The research was observational only and complied with protocols approved by the Animal Research Ethical Committee of the School of Arts, Sciences and Humanities, University of São Paulo (CEUA/EACH 002/2019); fully adhered to Brazilian law, under authorization from environmental agencies 
IBAMA/ICMBio 60134, and complied with the American Society of Primatologists Principles for the Ethical Treatment of Non-Human Primates.

\section{Author contributions}

TF and MDF designed the study, acquired funds, collected data, analyzed data, wrote, and reviewed the manuscript. TV collected data, analyzed data, wrote, and reviewed the manuscript. MPV collected data, wrote, and reviewed the manuscript.

\section{Competing Interests Statement}

The authors declare no competing interests

\section{Figures}




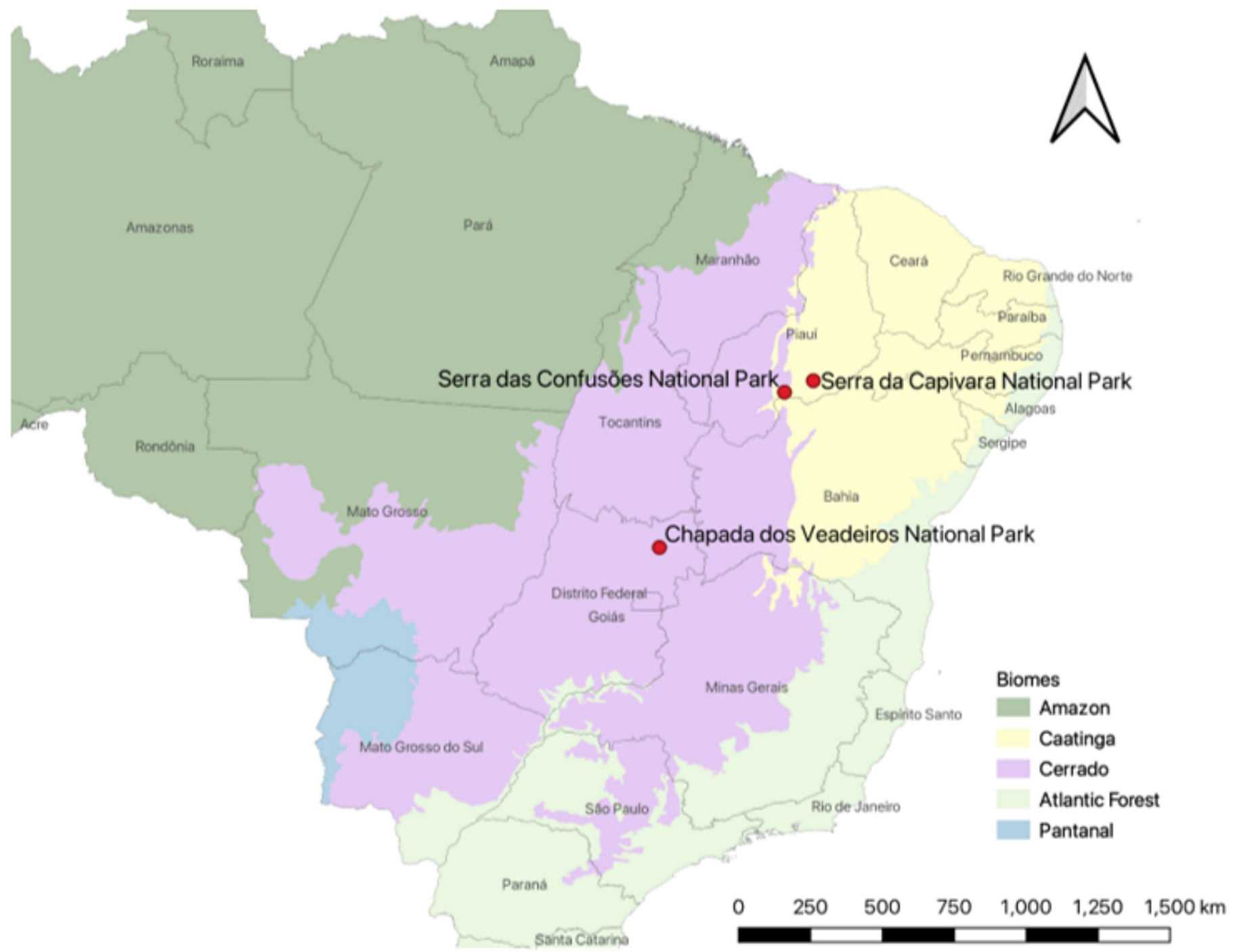

\section{Figure 1}

Map of Brazil with the locations of the study sites on this work (red dots). Biomes are indicated by color (see legend). Map by Tiago Falótico. 


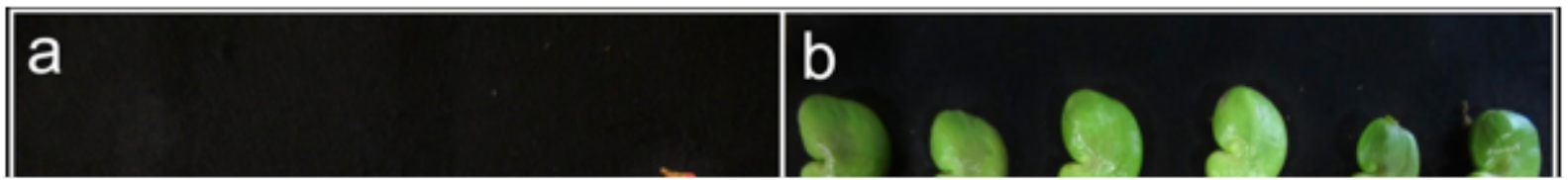

\section{Figure 2}

Food resources sampled. (a) Dry cashew nut, Anacardium; (b) fresh cashew nut, Anacardium; (c) palm nut, Attalea; (d) jatoba pod, Hymenaea; (e) Manihot seed; (f) Mirindiba, Buchenavia grandis. 


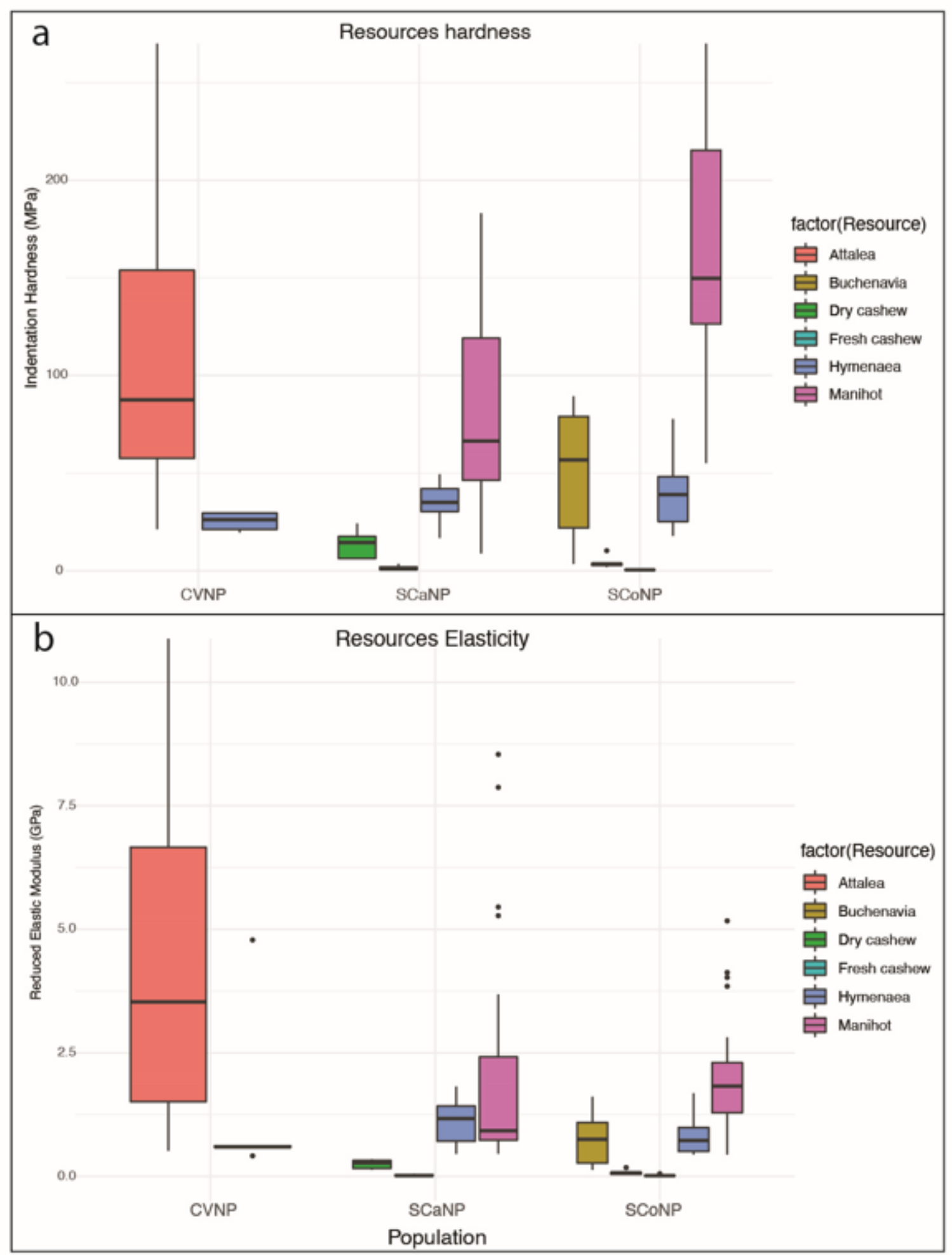

Figure 3

Physical properties of the food resources processed with stone tools in each study site. (a) Food resources hardness per study site. (b) Food resources elasticity per study site 


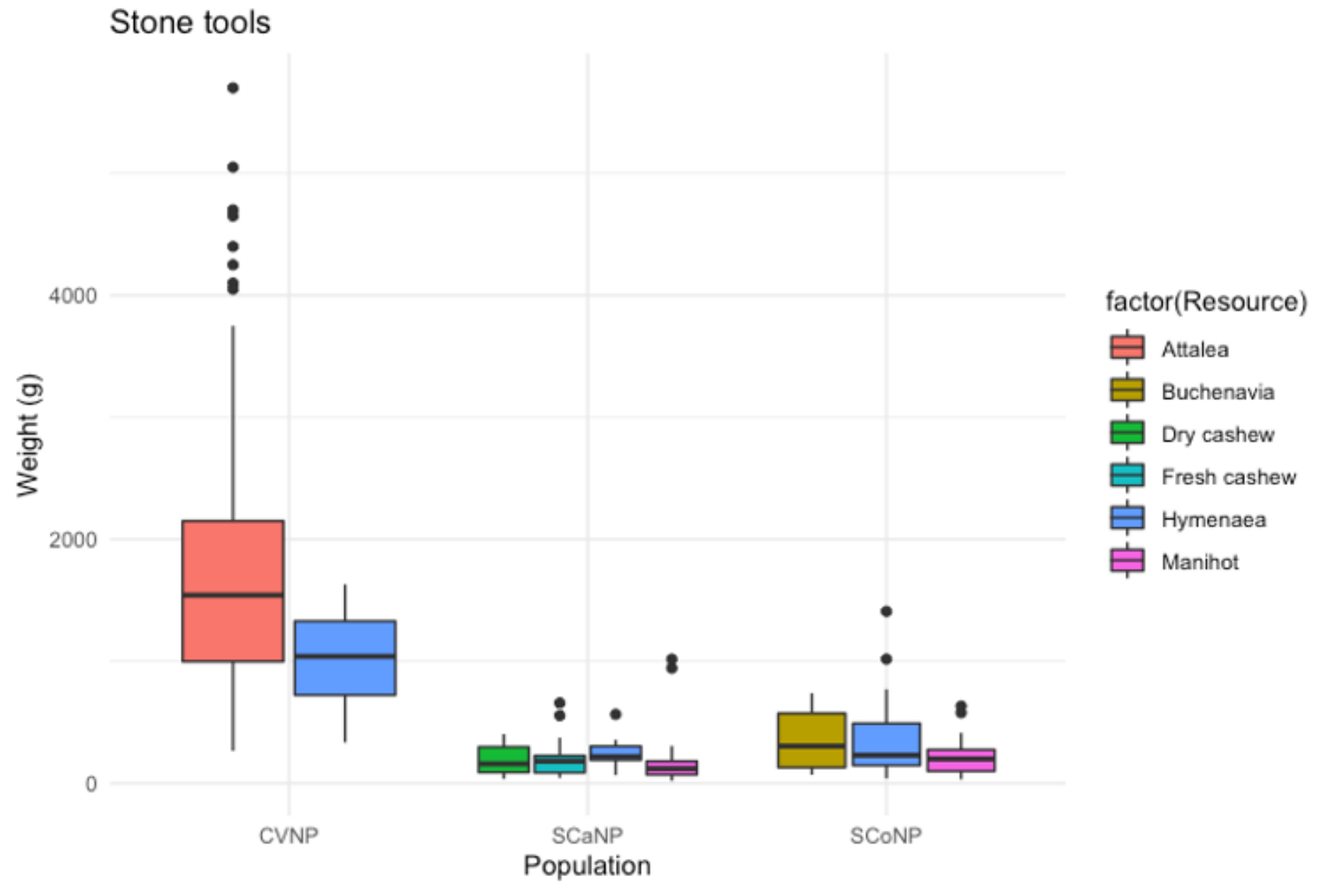

\section{Figure 4}

Hammerstone tool weight to process each resource at each site.

a

Figure 5

(a) Capuchin monkey from CVNP recorded on camera-trap using a $4650 \mathrm{~g}$ stone tool to crack open an Attalea palm nut. (b) The stone tool used. $10 \mathrm{~cm}$ scale. 


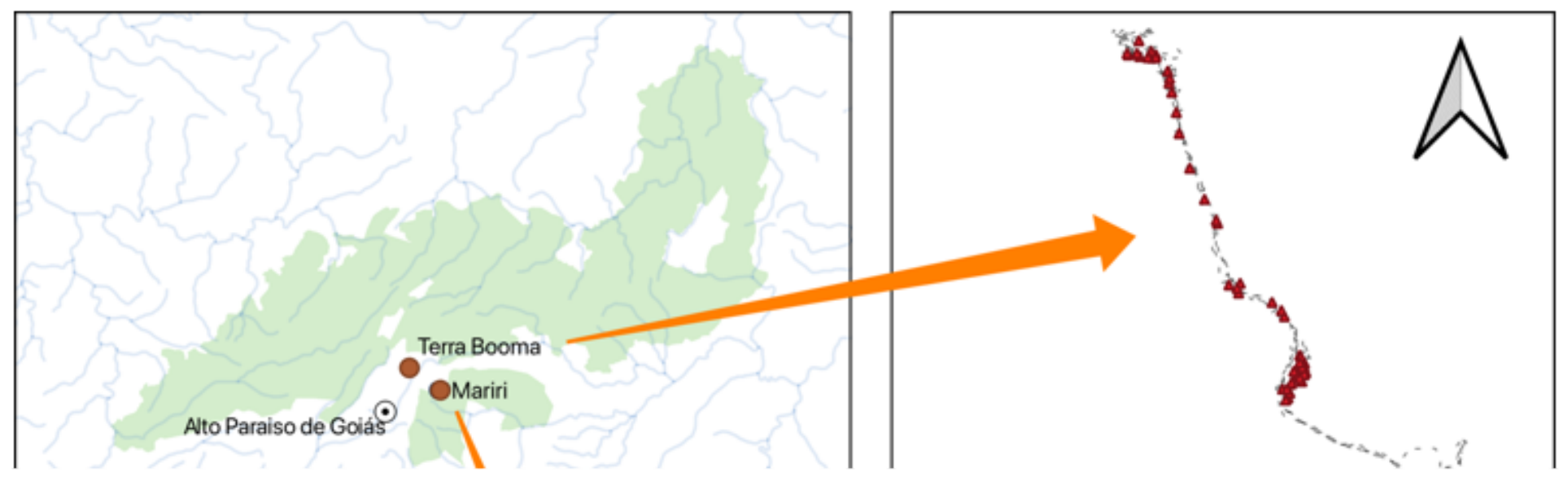

\section{Figure 6}

Map of trails and tool use sites (red triangles) recorded at Chapada dos Veadeiros National Park (CVNP), in two locations, Mariri (bottom) and Terra Booma (upper right). Plot sample locations at Mariri study site (bottom map, blue dots). Map by Tiago Falótico.

\section{Supplementary Files}

This is a list of supplementary files associated with this preprint. Click to download.

- SupplementaryTable1StonesresourcesR.csv

- SupplementaryVideo120190726091807260098.mp4 
- SupplementaryVideo220190809101808090142.mp4

- SupplementaryVideo320190813100708130106.mp4 